\title{
Sucrose Metabolism During Papaya (Carica papaya) Fruit Growth and Ripening
}

\author{
Lili Zhou, ${ }^{1}$ and Robert E. Paull ${ }^{2}$ \\ Department of Tropical Plant and Soil Sciences, College of Tropical Agriculture and Human Resources, \\ University of Hawaii at Manoa, 3190 Maile Way, Honolulu, HI 96822-2279
}

ADDITIONAL INDEX WORDS. sweetness, carbon import rates, fruit growth, seed development, postharvest

\begin{abstract}
Papaya (Carica papaya L.) fruit flesh and seed growth, fruit respiration, sugar accumulation, and the activities of sucrose phosphate synthase (SPS), sucrose synthase (SS), and acid invertase (AI) were determined from anthesis for $\approx 150$ days after anthesis (DAA), the full ripe stage. Sugar began to accumulate in the fruit flesh between 100 and 140 DAA, after seed maturation had occurred. SPS activity remained low throughout fruit development. The activity of SS was high $14 \mathrm{DAA}$ and decreased to less than one-fourth within $56 \mathrm{DAA}$, then remained constant during the remainder of fruit development. AI activity was low in young fruit and began to increase 90 DAA and reached a peak more than 10-fold higher, 125 DAA, as sugar accumulated in the flesh. Results suggest that SS and AI are two major enzymes that may determine papaya fruit sink strength in the early and late fruit development phases, respectively. AI activity paralleled sugar accumulation and may be involved in phloem sugar unloading.
\end{abstract}

Source-sink relationships play a key role in fruit and seed development and the accumulation and composition of sugars during fruit ripening (Hawker 1969; Hubbard et al., 1989; Klann et al., 1993; Pavel and DeJong, 1993). In particular, sink strength influences the levels of specific sugars such as fructose, glucose, and sucrose that also determine fruit quality and flavor (Wang et al., 1993). Depending upon plant species, tissue and stages of fruit development, three enzymes vary in their activity in relation to sink strength and sugar accumulation (Hubbard et al., 1989; Lingle and Dunlap, 1987; Miron and Schaffer, 1991; Moriguchi and Yamaki, 1988; Wang et al., 1993; Yelle et al., 1991). Sucrose phosphate synthase (SPS) (UDPG: D-fructose 6-2-glucosyltransferase E.E.2.4.1.14) is involved in sucrose synthesis, and, sucrose synthase (SS) (UDPG: D-fructose 2-glucosyltransferase,E.C.2.4.1.13) functions both in sucrose synthesis and cleavage. Acid and neutral invertases ( $\beta$-fructofuranosidase, E.C.3.2.1.26) catalyze the hydrolysis of sucrose to fructose and glucose (McCollum et al., 1988).

The pathways for fruit sucrose accumulation among different species have been categorized as the acid invertase (AI) type, the SPS type, the SS type and the SS/SPS type (Yamaki 1995). Development studies of papaya (Carica papaya) fruit have shown that total sugar, especially sucrose, increases rapidly, $\approx 20$ to $30 \mathrm{~d}$ before fruit ripening (Chan et al., 1979; Selvaraj et al., 1982; Zhou et al., 2000). High soluble AI activity (Chan and Kwok, 1976) and low SPS and SS activities have been found in ripe papaya fruit mesocarp (Hubbard et al., 1991), suggesting that papaya may be of the AI type. However, the activities of the key enzymes have not been related to papaya fruit growth and development or to sucrose accumulation. The objective of this study was to determine the time course and the relationship between fruit fresh weight (FW), skin, and flesh (mesocarp) color, dry weight (DW), sugar accumulation,

Received for publication 24 Feb. 2000. Accepted for publication 27 Nov. 2000. College of Tropical Agriculture and Human Resources Journal Series 4495. This research was funded by U.S. Department of Agriculture-Cooperative State Research Extension and Experiment Stations Grants 96-34135-2842 and 9834135-6458. The research represents a portion of a dissertation submitted by the senior author for the PhD in Horticulture. We thank Gail Uruu and Nancy Chen for technical assistance. The cost of publishing this paper was defrayed in part by the payment of page charges. Under postal regulations, this paper therefore must be hereby marked advertisement solely to indicate this fact.

${ }^{1}$ Post doctoral fellow.

${ }^{2}$ Professor and corresponding author; e-mail: <paull@hawaii.edu>. and the activities of SPS, SS and AI during papaya fruit development and ripening. In addition, the patterns of these enzymes' activities during late fruit development were compared between a low-sugar accumulating breeding line and commercial cultivars. An understanding of the biochemistry and key enzymes involved in sucrose accumulation in papaya is a prerequisite to possible genetic improvement of the sweetness of this fruit.

\section{Materials and Methods}

Plant material, developmental stages, and observations. Plants of Carica papaya, 'Sunset' and 'Waimanalo', and a low sugar breeding line UH801 were grown at the Poamoho Experiment Station (Central Oahu, Hawaii). Fruit of 'Line 8' and 'Kapoho' were obtained directly from nearby fields of the Dole Food Company in central Oahu. Results from 'Sunset' were used to illustrate the changes, and compared with other commercial lines ('Kapoho', 'Waimanalo', and 'Line 8'). Only limited quantities of UH801 fruit were available, and, were used to determine sugar accumulation and enzyme activity. 'Sunset' and 'Kapoho' fruit development was divided into stages based on weekly tagging of flowers at anthesis. When the first tagged 'Sunset' fruit skin reached the color break to $20 \%$ yellow stage, all fruit on one plant, 14 to $140 \mathrm{~d}$ after anthesis (DAA), were harvested. All fruit on different plants were harvested over the subsequent 2 weeks. These fruit were separated into 10 stages (treatments), with eight plants (replicates) at the two harvest dates (subsamples), and two to four fruit per stage per plant per harvest date (samples). All data presented were means of the two harvest subsamples within each treatment unless otherwise indicated. The fruit stages for UH801 and other cultivars were estimated by fruit skin and flesh color. For comparison of fruit sugar and SPS, SS, and AI activities of all five cultivars during the postharvest ripening period, fruit were harvested from color break to $30 \%$ skin yellow stage, stored at $22^{\circ} \mathrm{C}$ and sampled 1,3 and $7 \mathrm{~d}$ after harvest.

Fruit weight (FW) (g/fruit), total soluble solids (TSS\%), fruit skin and flesh color, and fruit respiration rate was measured for all fruit harvested. Fruit sugar $\left(\mathrm{g} \cdot \mathrm{kg}^{-1} \mathrm{FW}\right)$, flesh, seed FW (g/fruit), DW and SPS, SS, and AI activity were determined on fruit from the 10 stages. Skin and flesh color were determined at the fruit equatorial area with a colorimeter (CR-300, Minolta Co., Ramsey, N.J.), as CIE (Commission Internationale de I'Eclairage) 'L', 'a', and, 'b' value for each fruit. 
Sugar DETERMination. TSS was determined by refractive index from two flesh samples taken at the fruit equatorial area. Two grams of flesh tissue in $1 \mathrm{~mL}$ deionized water were heated for $10 \mathrm{~min}$ in a boiling water bath to inactivate invertase, before $17 \mathrm{~mL} 95 \%(\mathrm{v} / \mathrm{v})$ ethanol was added, homogenized, and centrifuged $10,000 g_{\mathrm{n}}, 20 \mathrm{~m}$. Five milliliters of the supernatant solution was dried and dissolved in 2.5 or $5 \mathrm{~mL}$ deionized water for young and mature fruit, respectively. Sucrose, fructose, and glucose were separated by highperformance liquid chromatography, the peaks identified by retention times, and, quantified by the peak area under known standards (Paull et al., 1984). The concentration of the three sugars was summed and regarded as the total.

GROWTH, RESPIRATION, AND CARBON IMPORT RATE. The percentage DW for each sample stage was determined by drying $10 \mathrm{~g}$ tissue or seed $(n=3)$ for $6 \mathrm{~d}$ at $60^{\circ} \mathrm{C}$ (Qiu et al., 1995). Fruit flesh and seed DW accumulation were calculated from percentage DW multiplied by the average fruit FW at the same development stage. The growth rate (GR) of flesh and seed DW growth rate per fruit was calculated. Respiration rates were determined by sealing individual fruit for 1 $\mathrm{h}$ in a $970 \mathrm{~mL}$ jar at $22 \mathrm{EC}$, and, the free air volume adjusted for fruit weight, $1 \mathrm{~mL}$ headspace gas was sampled for $\mathrm{CO}_{2}$ measurement. An infrared gas analyzer was used to determine $\mathrm{CO}_{2}$ concentration (Clegg et al., 1978). Carbon import rates were calculated from the sum of carbon consumed by respiration per fruit per day, and, carbon accumulated in fruit per day as the growth rate of DW multiplied by 0.47 (Huang et al., 1992).

ENZYME EXTRACTION AND ENZYME ASSAYS. SPS, SS, and AI enzymes were extracted according to Hubbard et al. (1989), with slight modifications. Fruit was sliced, the skin and seeds removed, the mesocarp tissue was cut into pieces, frozen in liquid $\mathrm{N}_{2}$ and stored at $-80^{\circ} \mathrm{C}$ until used. Frozen tissue was ground in a liquid $\mathrm{N}_{2}$ chilled mortar and pestle; $3 \mathrm{~g}$ of powder was transferred to a centrifuge tube that contained $12 \mathrm{~mL}$ of extraction buffer $(100 \mathrm{~mm}$ 3-[N-morpholino]propanesulfonic acid (MOPS-NaOH) (pH 7.5), 5 $\mathrm{mm} \mathrm{MgCl}_{2}, 1$ mu ethylenediaminetetraacetic acid (EDTA), $2.5 \mathrm{~mm}$ dl-dithiothreitol (DTT), bovine serum albumin (BSA) $0.5 \mathrm{mg} \cdot \mathrm{mL}^{-}$ ${ }^{1}, 2 \%$ (v/v) glycerol, 1 mm phenylmethylsulfonyl fluoride (PMSF), $0.05 \%(\mathrm{v} / \mathrm{v})$ Triton X-100), and homogenized for $30 \mathrm{~s}$ to $1 \mathrm{~min}$ at high speed in a Ultra-Turrax homogenizer (Tekmar Co., Cincinnati, Ohio). Aftercentrifugation at $10,000 g_{n}, 10 \mathrm{~min}, 5 \mathrm{~mL}$ of supernatant was desalted and concentrated through Centriflo membrane cones (CF-25, Amicon Inc, Beverly, Mass.) by three additions of desalting buffer (50 mм MOPS-NaOH (pH 7.5), 5 mм $\mathrm{MgCl}_{2}, 2.5$ mм DTT, $0.5 \mathrm{mg} \cdot \mathrm{mL}^{-1} \mathrm{BSA}$, and $1 \mathrm{~mm}$ PMSF). The final solution volume was measured, and the concentration factor calculated.

The reaction mixture $(70 \mu \mathrm{L})$ used to determine SPS contained 50 mм MOPS-NaOH (pH 8.0), 15 mм $\mathrm{MgCl}_{2}, 10$ mм fructose 6-P,

Fig. 1. Changes in 'Sunset' papaya (A) fruit skin CIE value 'b' and flesh CIE value 'a', (B) flesh and seed fresh weight (FW), (C) dry weight (DW) accumulation of whole fruit, flesh, and seed, (D) DW percentage of seed and flesh, (E) respiration rate, and, $(F)$ flesh and seed DW growth rate, during fruit development as days after anthesis. Papaya skin ' $b$ ' value $=0.0034+X^{2}-0.598+X+40.48$, $R^{2}=0.7903, P=0.0001$; Papaya flesh 'a' value $=0.00007+\mathrm{X}^{3}-0.014+\mathrm{X}^{2}+$ $0.724+\mathrm{X}-15.37, R^{2}=0.8673, P=0.0001 ;$ Fruit flesh fresh growth $=-0.0002$ $+\mathrm{X}^{3}+0.0277+\mathrm{X}^{2}+1.2749+\mathrm{X}-20.601, R^{2}=0.9982, P=0.0001 ;$ Seed fresh growth $=-0.00003+\mathrm{X}^{3}+0.007+\mathrm{X}^{2}-0.223+\mathrm{X}+3.2524, R^{2}=0.9999, P=$ $0.0001 ;$ DW growth for whole fruit $=0.00002+X^{3}-0.0023+X^{2}+0.2556+$ $\mathrm{X}-2.6805, R^{2}=0.999, P=0.001 ; \mathrm{DW}$ growth for flesh $=0.00007+\mathrm{X}^{3}-0.0181$ $+\mathrm{X}^{2}+1.6362+\mathrm{X}-41.551, R^{2}=0.9997, P=0.001 ; \mathrm{DW}$ growth for seed $=-$ $0.00003+\mathrm{X}^{3}+0.0074+\mathrm{X}^{2}-0.5906+\mathrm{X}+15.401, R^{2}=0.9989, P=0.001 ;$ Fruit respiration rate $=0.0522+X^{4}-1.3806+X^{3}+13.138+X^{2}-52.687+X+88.18$, $R^{2}=0.9863, P=0.001$. For FW and respiration rate, each data point represents a mean of at least 16 fruit. For DW percentage, each data point represents the mean of three pooled samples.
$30 \mathrm{~mm}$ glucose 6-P, $20 \mathrm{~mm}$ UDPG, and $45 \mu \mathrm{L}$ desalted enzyme extract. Reaction mixtures were incubated at $37^{\circ} \mathrm{C}$ with shaking and the reaction terminated at 0 and $30 \mathrm{~min}$ by addition of $70 \mu \mathrm{L} 30 \%$ $(\mathrm{W} / \mathrm{V}) \mathrm{KOH}$ and placing the tubes in a boiling water bath for 10 min. After cooling to ambient temperature, $1 \mathrm{~mL}$ of $0.14 \%(\mathrm{w} / \mathrm{v})$ anthrone in $14 \mathrm{M} \mathrm{H}_{2} \mathrm{SO}_{4}$ was added (Hubbard et al., 1989) and incubated at $40{ }^{\circ} \mathrm{C}$ for $20 \mathrm{~min}$. After cooling, color development was measured at $620 \mathrm{~nm}$. SS assay (in the sucrose direction) was identical to that of SPS except that the reaction mixtures contained $40 \mathrm{~mm}$ fructose and no fructose 6-P or glucose 6-P (Hubbard et al., 1989). Invertase was assayed in $60 \mu \mathrm{L} 0.1 \mathrm{M}$ $\mathrm{K}_{2} \mathrm{HPO}_{4}-0.1 \mathrm{M}$ citrate buffer (pH 5.0), $20 \mu \mathrm{L} 0.1 \mathrm{M}$ sucrose, and $20 \mu \mathrm{L}$ concentrated or diluted enzyme extract at $22{ }^{\circ} \mathrm{C}$. The reaction was stopped by adding $1 \mathrm{~mL}$ borate buffer $(\mathrm{pH} 9.0)$ and reducing sugar determined by adding $0.2 \mathrm{~mL} 1 \%$ (w/v) cyanoacetamide and boiling the mixture for $10 \mathrm{~min}$, absorbancy was read at $276 \mathrm{~nm}$, and glucose and fructose were used as standards (Gross, 1988).

Data ANALYSIS. Statistical analysis was performed using Excel (Microsoft Co., Redmond, Wash.) and the SAS (SAS Inst., Inc., Cary, N.C.) general linear models and correlation program. Means were separated by Duncan's multiple range test and LSD.

\section{Results}

FruIT SKIN AND FLESH COLOR DEVELOPMENT. During the warm season 'Sunset' papaya fruit reached full size and had a trace of yellow skin 140 DAA. Skin CIE 'L' (lightness) and 'b' (blue to
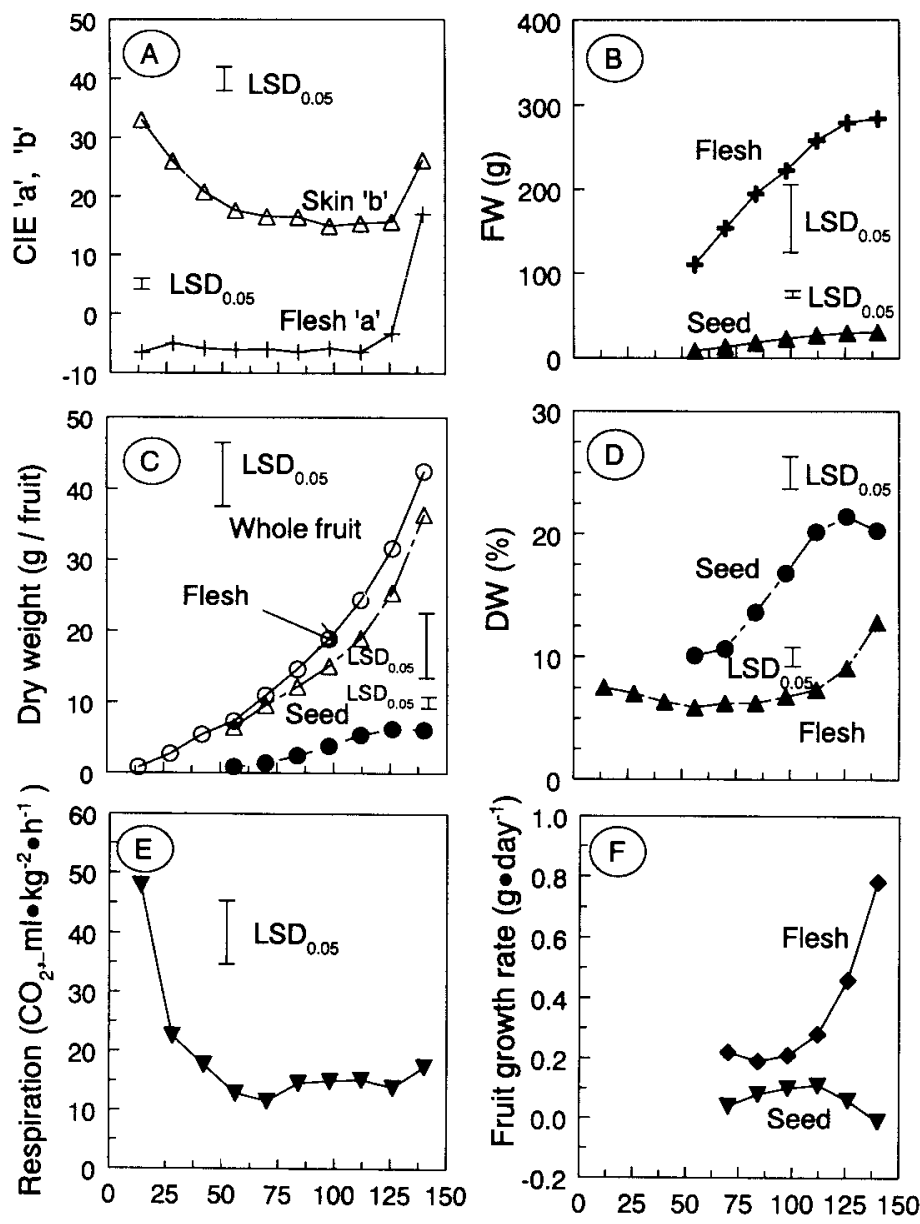

Days from anthesis 

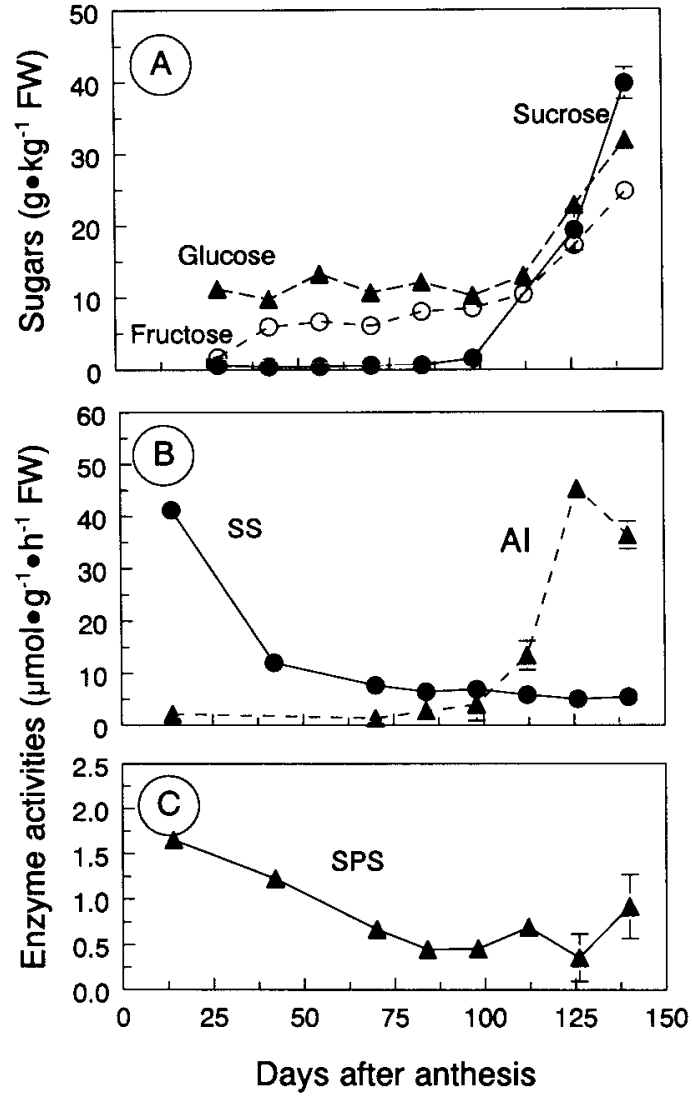

Fig. 2. Time course of (A) mesocarp sugar accumulation and the activities of (B) SS and AI and (C) SPS, during 'Sunset' papaya fruit development, as days after anthesis. In A each data point represents the mean $(n=3) \pm$ SD of extractions of sugar and in $\mathrm{B}$ and $\mathrm{C}$ each data point represents the mean $(\mathrm{n}=2) \pm \mathrm{sD}$ of enzyme activities.

yellow) values were initially high, and decreased gradually from 15 to 112 DAA (Fig. 1A). There was large variation in skin 'b' value between replicates during ripening and this variation reflected the rapid color changes. The skin ' $a$ ' value increased from $<0$ to 6 , and ' $b$ ' value from 15 to 25 during ripening as the fruit turned yellow. Flesh lightness 'L' remained high (.80) while the flesh was still white until $\approx 1$ month before ripening commenced, then declined significantly as ripening commenced (.50). The red-orange flesh ('a' green to red) increased from -5 , at 125 DAA (Fig. 1A), to 18 during fruit ripening. Papaya seed changed from white to brown $\approx 1$ month before harvest (112 DAA), then turned black $\approx 14 \mathrm{~d}$ before ripening commenced (data not presented).

FrUIT GROWTH AND RESPIRATION RATE. There was a near-linear increase in both flesh and seed FW from 70 to 112 DAA (Fig. 1B). Fruit dry matter increased gradually between 14 to 96 DAA, then increased rapidly between 96 to 140 DAA (Fig. 1C). The percentage of fruit flesh DW decreased slightly between 14 to 56 DAA, then remained constant from 70 to $112 \mathrm{DAA}$, and increased again $\approx 1$ month before the start of ripening. The seed DW percentage rapidly increased from 70 to $126 \mathrm{DAA}$, then declined just before the start of ripening (Fig. 1D). Fruit respiration rate of $\mathrm{CO}_{2}$ (Fig. 1E) decreased from $48 \mathrm{~mL} \cdot \mathrm{h}^{-1} \cdot \mathrm{kg}^{-1}$ in fruit 14 DAA to $12 \mathrm{~mL} \cdot \mathrm{h}-$ ${ }^{1} \cdot \mathrm{kg}^{-1}$ at 70 DAA, then remained constant until the skin of the fruit changed as ripening commenced. As the growth rate of seed DW increased 70 to 112 DAA (Fig. 1F), the growth rate of flesh DW decreased or slightly increased. Flesh DW growth rate increased rapidly 112 to $140 \mathrm{DAA}$ (Fig. $1 \mathrm{~F}$ ), at the same time as sugar accumulated (Fig. 2A).

Fruit SUgars AND ENZYME aCTIVITy. Fruit glucose, fructose, and sucrose in the flesh did not increase significantly until $\approx 112$ DAA in 'Sunset' (Fig. 2A), $\approx 1$ month before ripening commenced. Sucrose accounted for $40 \%$ to $50 \%$ of total sugar in mature fruit just prior to ripening. 'Kapoho' and 'Sunset' showed sugar accumulation pattern similar to the low sugar breeding line UH801 (Table 1).

SS activity assayed in the synthesis direction at $\mathrm{pH} 8.0$ had a higher activity than at $\mathrm{pH} 7.5$ (data not presented). Activity of SS was very high $\left(>40 \mu \mathrm{mol} \cdot \mathrm{g}^{-1} \cdot \mathrm{h}^{-1}\right)$ in young fruit (14 DAA), declined at 56 DAA to $12 \mu \mathrm{mol} \cdot \mathrm{g}^{-1} \cdot \mathrm{h}^{-1}$, and, then remained relatively low during the remainder of fruit development (Fig. 2B). As fruit began to ripen, with a trace of skin color yellowing, SS activity increased by $\approx 30 \%, 14 \mathrm{~d}$ before ripening commenced (Table 2). AI activity was very low in the young fruit and began to increase (90 DAA) to more than 10-fold higher (125 DAA), before ripening commenced (139 DAA) (Fig. 2B) and this increase paralleled sugar accumulation (Fig. 2A). Invertase activity varied greatly $14 \mathrm{~d}$ before ripening commenced and was higher in the outer white flesh tissue ( $14 \mathrm{~d}$ before ripening) than in the inner riper flesh tissue (Table 2). Neutral or alkaline invertases were not detected in either young or ripe papaya fruit (data not presented). During fruit development SPS remained low and increased only slightly in mature fruit (Fig. 2C). The difference in SPS activity between each developmental stage was not significant.

TSS, ENZYME ACTIVITY, RIPENING, AND SUGAR ACCUMULATION. Papaya fruit skin color changed rapidly during postharvest ripening while flesh color and fruit sugar remained constant. A quantitative relationship was obtained between flesh 'a' value (green to red) and fruit TSS (Fig. 3): Flesh 'a' $=-0.28+\mathrm{TSS}^{2}+7.91+\mathrm{TSS}-32.708$ $\left(R^{2}=0.6702, P=0.0001\right)$. Fruit flesh 'a' color increased rapidly $(0$ to 19 ) as fruit TSS increased from 5\% to $10 \%$, however, once fruit TSS exceeded $10 \%$, the flesh 'a' value increased from 19 to 21 while TSS increased from $10 \%$ to $16 \%$.

Correlation analysis indicated that SS was positively correlated with fruit respiration $\left(R^{2}=0.9526, P=0.00004\right)$. The correlation coefficient between acid invertase activity and fruit sugar accumu-

Table 1. Comparison of sugar content, on a fresh weight (FW) basis, in the mesocarp of commercial 'Kapoho' papaya and a low sugar breeding line UH 801 during late fruit development stages, [4 weeks before ripening (4 wk), and 2 weeks before ripening ( 2 wk)], and at the color break stage when fruit skin showed a trace of yellow indicating maturity and ripening.

\begin{tabular}{|c|c|c|c|c|c|c|c|c|c|}
\hline \multirow[b]{3}{*}{ Genotype } & \multicolumn{9}{|c|}{ Flesh sugar content $\left(\mathrm{g} \cdot \mathrm{kg}^{-1} \mathrm{FW}\right)^{\mathrm{z}}$} \\
\hline & \multicolumn{3}{|c|}{ Glucose } & \multicolumn{3}{|c|}{ Fructose } & \multicolumn{3}{|c|}{ Sucrose } \\
\hline & $4 \mathrm{wk}$ & $2 \mathrm{wk}$ & Mature & $4 \mathrm{wk}$ & $2 \mathrm{wk}$ & Mature & $4 \mathrm{wk}$ & $2 \mathrm{wk}$ & Mature \\
\hline Kapoho & $16 \mathrm{a}$ & $18 \mathrm{a}$ & $25 \mathrm{a}$ & $10 \mathrm{a}$ & $12 \mathrm{~b}$ & $25 \mathrm{a}$ & $1 \mathrm{a}$ & $11 \mathrm{a}$ & $53 \mathrm{a}$ \\
\hline UH 801 & $16 \mathrm{a}$ & $12 \mathrm{~b}$ & $14 \mathrm{~b}$ & $11 \mathrm{a}$ & $17 \mathrm{a}$ & $18 \mathrm{~b}$ & $3 a$ & $10 \mathrm{~b}$ & $17 \mathrm{~b}$ \\
\hline
\end{tabular}

${ }^{\mathrm{z}}$ Mean separation within columns by Duncan's multiple range test, $P \leq 0.05,(\mathrm{n}=3)$. 
Table 2. Activities of sucrose (FW = fresh weight) phosphate synthase $(\mathrm{SPS})$, sucrose synthase $(\mathrm{SS})$, and acid invertase $(\mathrm{AI}) \pm \mathrm{SD}(\mathrm{n}=3)$ in winter grown 'Sunset' papaya harvested 4 and 2 weeks before maturity, and at maturity when the fruit showed a trace of skin yellowing indicating ripening. Two weeks before harvest the fruit mesocarp was divided into outer and inner mesocarp, as the fruit ripened from the inside outwards.

\begin{tabular}{|c|c|c|c|}
\hline \multirow[b]{2}{*}{ Fruit tissue } & \multicolumn{3}{|c|}{ Enzyme activity (sucrose, $\mu \mathrm{mol} \cdot \mathrm{g}^{-1} \cdot \mathrm{h}^{-1} \mathrm{FW}$ ) } \\
\hline & SPS $^{Y}$ & SS & $\mathrm{AI}$ \\
\hline \multicolumn{4}{|l|}{ Before maturity } \\
\hline 4 weeks & $1.1 \pm 0.08$ & $4.2 \pm 0.2$ & $31.1 \pm 2.5$ \\
\hline \multicolumn{4}{|l|}{2 weeks } \\
\hline Outer mesocarp & $1.6 \pm 1.55$ & $6.2 \pm 0.3$ & $74.7 \pm 3.5$ \\
\hline Inner mesocarp & $1.6 \pm 0.14$ & $4.3 \pm 0.3$ & $46.9 \pm 3.3$ \\
\hline Color break stage & $1.6 \pm 0.13$ & $4.6 \pm 0.3$ & $46.3 \pm 5.1$ \\
\hline
\end{tabular}

lation $\left(R^{2}=0.738, P=0.05\right)$ was higher $\left(R^{2}=0.93, P=0.0076\right)$, when invertase activity in fruit $14 \mathrm{~d}$ earlier than the fruit sugar sampling date was used.

CARBON IMPORT AND ENZYME ACTIVITY IN FRUIT FLESH TISSUE. Relationships between calculated daily carbon import per fruit, SS, and AI enzyme activities in fruit were logarithmic and quadratic, respectively (Fig. 4). SS activity on a whole fruit basis increased rapidly during early fruit development (Carbon import rate $=0.067$ + SS activity $\left.-4.09,\left[R^{2}=0.858, P=0.0009\right]\right)$, and then remained constant while carbon import increased rapidly during fruit maturation (Fig. 4A). Invertase was initially low (Fig. 4B) and did not increase until the carbon import rate increased at the late fruit development stage [Carbon import rate $=-6.2 \times 10^{-8}+$ invertase activity $^{3}+2.34 \times 10^{-5}+$ invertase activity ${ }^{2}-0.00049+$ invertase activity $\left.+0.1018,\left(R^{2}=0.918, P=0.039\right)\right]$. A linear correlation existed between SPS and fruit carbon import (Fig. 4C), though SPS activity was less than one tenth that of SS, and invertase activities during papaya fruit development. The significantly lower sugar level in UH801 than 'Kapoho', was correlated to lower invertase

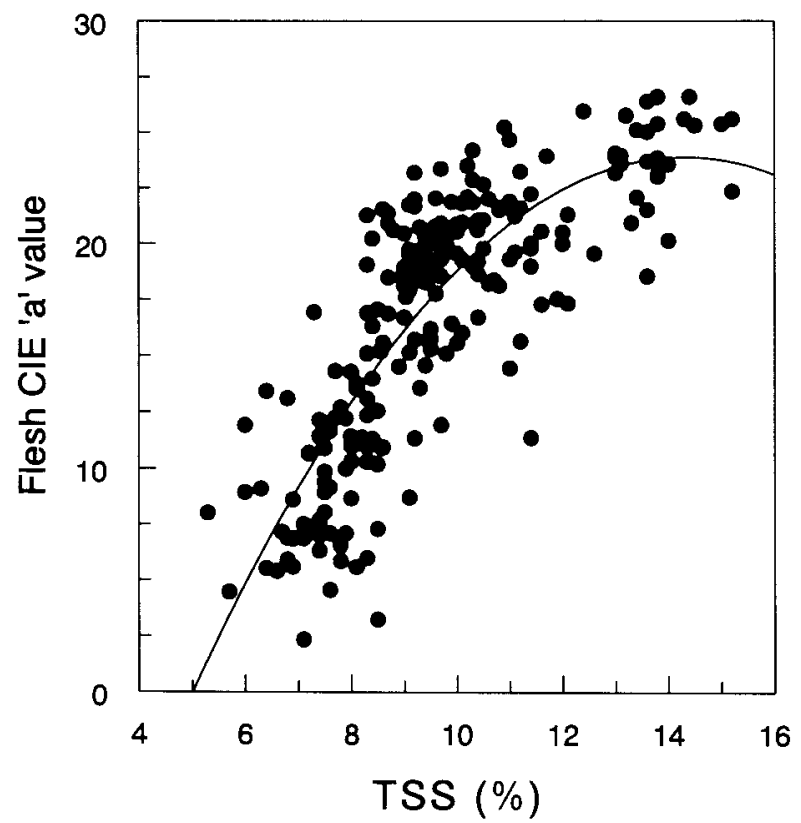

Fig. 3. Statistical relationship, between fruit flesh 'a' color and TSS levels in ripe 'Sunset' papaya fruit. Fruit were harvested at color break to $30 \%$ yellowing, stored for 7 to $10 \mathrm{~d}$ at $22^{\circ} \mathrm{C}$ until the fruit reached full skin yellow and soft. Each data point represents the mean of two measurements for each fruit. Color ' $\mathrm{a}$ ' $=$ $-0.2767+\mathrm{TSS}^{2}+7.9144+\mathrm{TSS}-32.708, R^{2}=0.6742, P=0.0001, \mathrm{n}=213$. and SPS activities, UH 801 had similar levels of SS as 'Kapoho' (Fig. 5).

SUGAR CONCENTRATION AND ENZYME ACTIVITIES DURING POSTHARVEST RIPENING. Total sugar concentration and percentage sucrose in the five cultivars from 1 to $7 \mathrm{~d}$ after harvest varied widely (Table 3 ). The average sucrose percentage was significantly higher in 'Kapoho', than in the other cultivars (Table 3). 'Sunset', 'Kapoho', 'Line-8' and 'Waimanalo' had about

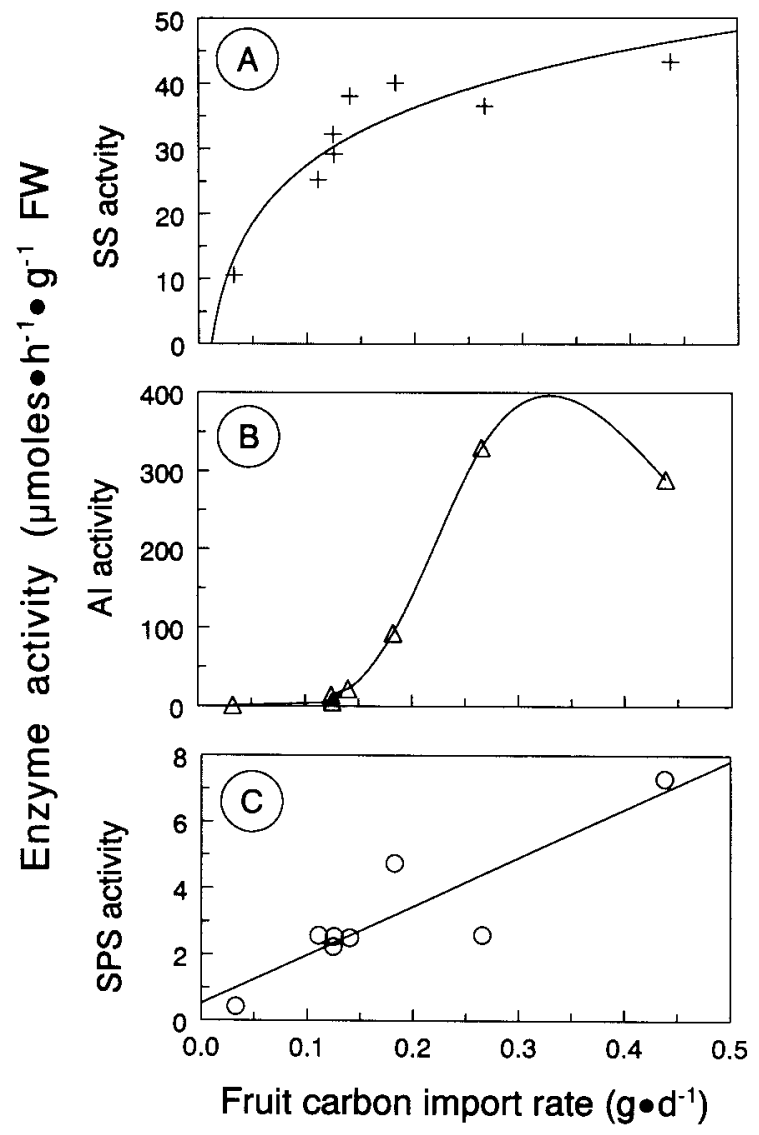

Fig. 4. Relationship between calculated fruit flesh carbon import rates [carbon consumed by respiration and daily dry weight (DW) accumulate per fruit], and (A) SS, (B) AI, and (C) SPS enzyme activities $\left[\mu \mathrm{mol} \cdot \mathrm{h}^{-1} \cdot \mathrm{g}^{-1}\right.$ fresh weigth (FW)] during 'Sunset' papaya fruit development. Regression equation for carbon import and SS: $\operatorname{Ln}$ (Carbon import rate) $=0.067$ (SS activity) $-4.09, R^{2}=0.858$, $P=0.0009$; for carbon import and invertase: Carbon import rate $=-6.2 \times 10^{-8}$ + invertase activity ${ }^{3}+2.34 \times 10^{-5}+$ invertase activity $^{2}-0.00049+$ invertase activity $+0.1018, R^{2}=0.918, P=0.039$; for carbon import and SPS: Carbon import rate $=0.538+$ SPS $+0.0079, R^{2}=0.779, P=0.0037$. 


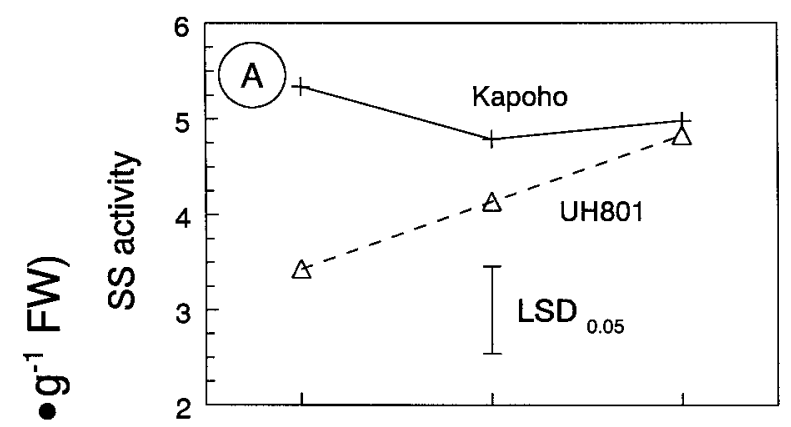

定
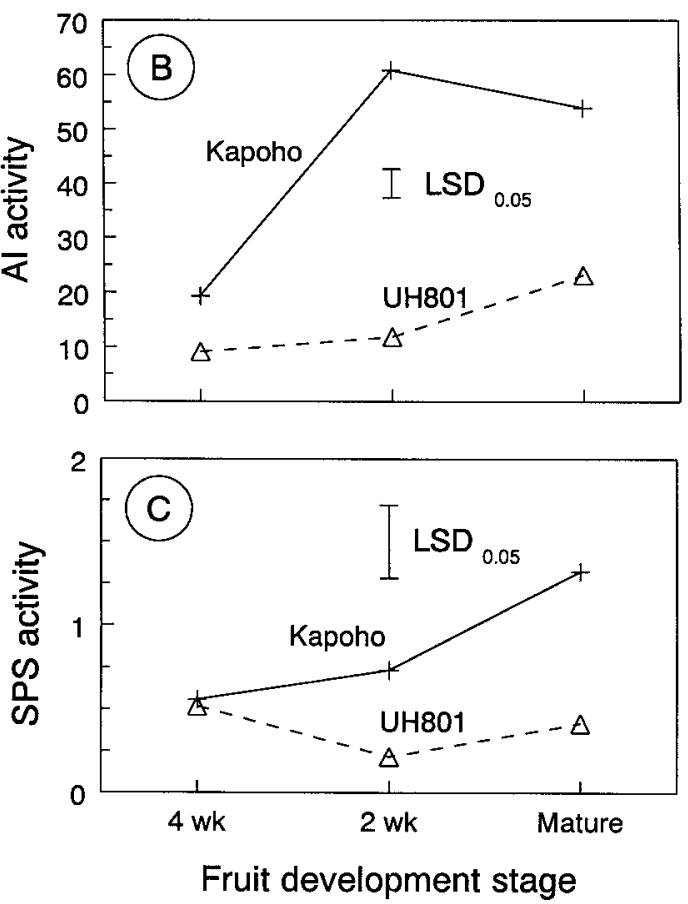

Fig. 5. Comparison of (A) SS, (B) AI, and (C) SPS enzyme activities $\left[\mu \mathrm{mol} \cdot \mathrm{h}^{-1} \cdot \mathrm{g}^{-1}\right.$ fresh weigth $(\mathrm{FW})]$ in 'Kapoho' and UH801 papaya during late fruit development stage; 4 weeks before harvest ( $4 \mathrm{wk}), 2$ weeks before harvest ( $2 \mathrm{wk}$ ) and color break stage (harvest maturity). In all figures each symbol is based on three observations.

twice the total sugar as UH801. The variability in sugar concentrations between cultivars at the three sampling times was probably due in part to cultivars and to fruit being taken from different locations, on plants of different vigor as fruit became available. Papaya ripening was characterized by a large increase in AI activity, a decrease in SS activity, and a low SPS activity (Table 4). SPS activities remained low in all 4 cultivars and 1 breeding line at the three sampling times after harvest and there was no significant difference between cultivars and sample times (Table
4). SPS activities in 'Waimanalo' and UH801 cultivars were significantly higher than in other cultivars 3 and $7 \mathrm{~d}$ after harvest. UH801 had significantly higher SS activity than the other four cultivars. All cultivars showed the same postharvest trend in AI activity, though UH801 had about half the invertase activity of the other four cultivars. The much higher invertase and lower SS activities in Line- 8 than in other cultivars, $1 \mathrm{~d}$ after harvest (Table 4), paralleled earlier ripening of the fruit flesh before changes occurred in skin color (data not presented).

\section{Discussion}

Papaya fruit growth and development from pollination to maturation varies with the cultivar, age of bearing trees, time of the year of anthesis, and the stage selected as an index of fruit maturity (Nakasone, 1986; Selvaraj and Pal, 1982). 'Sunset' papaya fruit, on the same plant in the first and second years' plant growth, matured 140 to $180 \mathrm{~d}$ from June and December flowers, respectively. The variation in fruit maturation time was probably due to fruit growth and development being slowed mainly by temperature, and to a lesser extent by tree age and fruit competition. Unlike most other fruit species, papaya continually produces three to six new flowers per week (Nakasone, 1986). Different aged fruit on the same plant probably have different growth rates due to their positions in the fruit column, as found for tomato (Lycopersicon esculentum Mill) (Bangerth and Ho, 1984). DW of fruit flesh increased only after the rate of seed DW decreased (Fig. $1 \mathrm{~F})$, and suggested that papaya seed development needed to be completed before the last phase of flesh dry matter accumulation began. The pattern of sugar accumulation during papaya fruit development in 'Sunset' (Fig. 2A) was similar to that observed by others for different cultivars (Chan et al., 1979; Selvaraj et al., 1982).

Papaya flesh 'a' value (Fig. 1A), a measure of fruit maturation, DW percentage (Fig. 1D), and flesh growth rate (Fig. 1F) positively correlated with the increase of soluble sugars (Fig. 2A) from 112 to 140 DAA. A linear correlation existed between flesh 'a' value and TSS when TSS was $<10 \%$ (Fig. 3). When TSS was $>10 \%$, the ' $a$ ' value increased slowly. Flesh color development occurred (Fig. 1A) after sugar accumulation had begun (Fig. 2A) and was unlikely to be controlled by the same developmental signal. The close correlation between TSS and color ' $a$ ' value in full ripe papaya flesh tissue clearly suggested that sugar level may influence red flesh development, possibly as a substrate. Red flesh of papaya is due to $65 \%$ of the total carotenoids being lycopene (Yamamoto, 1964) and a correlation has been found between tomato soluble solids and lycopene and 'a' color value (Young et al., 1993). However, no information is available as to the mechanism, other than as a substrate, by which sugar levels

Table 3. Changes in fruit total sugar content $(\mathrm{FW}=$ fresh weight $)$ and the sucrose percentage during postharvest ripening of four papaya cultivars and a breeding line. Fruit were harvested between the color break stage and up to $30 \%$ yellow skin and allowed to ripen at $22{ }^{\circ} \mathrm{C}$. Sugar content was determined 1,3 , and $7 \mathrm{~d}$ after harvest.

\begin{tabular}{|c|c|c|c|c|c|c|c|c|}
\hline \multirow[b]{2}{*}{ Genotype } & \multicolumn{4}{|c|}{ Total sugar $\left(\mathrm{g} \cdot \mathrm{kg}^{-1} \mathrm{FW}\right)$} & \multicolumn{4}{|c|}{ Sucrose $(\%, \mathrm{w} / \mathrm{w})$} \\
\hline & Day 1 & Day 3 & Day 7 & Mean & Day 1 & Day 3 & Day 7 & Mean \\
\hline Sunset & $106 b^{z}$ & $137 \mathrm{a}$ & $123 \mathrm{a}$ & $122 \mathrm{a}$ & $46 c$ & $51 \mathrm{~b}$ & $33 \mathrm{e}$ & $44 \mathrm{c}$ \\
\hline Kapoho & $117 \mathrm{a}$ & $122 \mathrm{~b}$ & $115 \mathrm{~b}$ & $118 \mathrm{~b}$ & $59 \mathrm{a}$ & $56 \mathrm{a}$ & $62 \mathrm{a}$ & $59 a$ \\
\hline Line- 8 & $86 \mathrm{c}$ & $99 \mathrm{c}$ & $123 \mathrm{a}$ & $103 \mathrm{c}$ & $53 \mathrm{~b}$ & $54 \mathrm{a}$ & $50 \mathrm{~b}$ & $52 \mathrm{~b}$ \\
\hline Waimanalo & $113 \mathrm{a}$ & $118 \mathrm{~b}$ & $124 \mathrm{a}$ & $119 \mathrm{ab}$ & $54 \mathrm{~b}$ & $34 \mathrm{~d}$ & $45 c$ & $44 \mathrm{c}$ \\
\hline UH 801 & $59 \mathrm{~d}$ & $58 \mathrm{~d}$ & $53 \mathrm{c}$ & $57 \mathrm{~d}$ & $44 \mathrm{c}$ & $38 \mathrm{c}$ & $38 \mathrm{~d}$ & $40 \mathrm{c}$ \\
\hline
\end{tabular}

${ }^{\mathrm{z}}$ Mean separation within columns by Duncan's multiple range test, $P \leq 0.05,(\mathrm{n}=3)$. 
Table 4. Sucrose phosphate synthase (SPS), sucrose synthase (SS), and AI enzyme activities (FW = fresh weight) during postharvest ripening of four papaya cultivars and a breeding line. Fruit were harvested at the color break stage to $30 \%$ yellow skin stage and held for up to $7 \mathrm{~d}$ at $22^{\circ} \mathrm{C}$. Enzyme activity was determined 1,3 , and 7 days after harvest.

\begin{tabular}{|c|c|c|c|c|c|c|c|c|c|c|c|c|}
\hline \multirow[b]{4}{*}{ Genotype } & \multicolumn{11}{|c|}{ Enzyme activity $\left(\mu \mathrm{mol} \cdot \mathrm{g}^{-1} \cdot \mathrm{h}^{-1} \mathrm{FW}\right)^{\mathrm{z}}$} & \\
\hline & \multicolumn{4}{|c|}{ SPS } & \multicolumn{4}{|c|}{ SS } & \multicolumn{4}{|c|}{ AI } \\
\hline & \multicolumn{3}{|c|}{ Days after harvest } & \multirow[b]{2}{*}{ Mean } & \multicolumn{3}{|c|}{ Days after harvest } & \multirow[b]{2}{*}{ Mean } & \multicolumn{3}{|c|}{ Days after harvest } & \\
\hline & 1 & 3 & 7 & & 1 & 3 & 7 & & 1 & 3 & 7 & Mean \\
\hline Sunset & $1.1 \mathrm{a}^{\mathrm{z}}$ & $0.8 \mathrm{~b}$ & $0.5 \mathrm{~b}$ & $0.8 \mathrm{a}$ & $3.6 \mathrm{~b}$ & $2.2 \mathrm{~b}$ & $0.8 \mathrm{~b}$ & $2.2 \mathrm{~b}$ & $47 \mathrm{bc}$ & $285 \mathrm{ab}$ & $328 \mathrm{ab}$ & $220 \mathrm{ab}$ \\
\hline Kapoho & $1.3 \mathrm{a}$ & $0.7 \mathrm{~b}$ & $0.5 \mathrm{~b}$ & $0.9 \mathrm{a}$ & $5.0 \mathrm{a}$ & $1.6 \mathrm{c}$ & $0.2 \mathrm{c}$ & $2.3 \mathrm{~b}$ & $54 \mathrm{~b}$ & $203 \mathrm{~b}$ & $421 \mathrm{a}$ & $226 \mathrm{ab}$ \\
\hline Line-8 & $1.1 \mathrm{a}$ & $1.0 \mathrm{~b}$ & $0.8 \mathrm{~b}$ & $1.0 \mathrm{a}$ & $1.5 \mathrm{c}$ & $1.3 \mathrm{c}$ & $0.3 \mathrm{c}$ & $1.0 \mathrm{~d}$ & $147 \mathrm{a}$ & $238 \mathrm{~b}$ & $358 \mathrm{a}$ & $248 \mathrm{a}$ \\
\hline Waimanalo & $1.1 \mathrm{a}$ & $1.6 \mathrm{a}$ & $0.6 \mathrm{~b}$ & $1.1 \mathrm{a}$ & $3.4 \mathrm{~b}$ & $0.6 \mathrm{~d}$ & $0.4 \mathrm{bc}$ & $1.4 \mathrm{c}$ & $52 \mathrm{~b}$ & $301 \mathrm{a}$ & $240 \mathrm{~b}$ & $198 \mathrm{~b}$ \\
\hline UH 801 & $0.5 \mathrm{a}$ & $1.1 \mathrm{~b}$ & $1.7 \mathrm{a}$ & $1.1 \mathrm{a}$ & $5.3 \mathrm{a}$ & $2.8 \mathrm{a}$ & $1.3 \mathrm{a}$ & $3.1 \mathrm{a}$ & $19 \mathrm{c}$ & $97 \mathrm{c}$ & $208 \mathrm{bc}$ & $109 \mathrm{c}$ \\
\hline
\end{tabular}

${ }^{\mathrm{z}}$ Mean separation within columns by Duncan's multiple range test, $\mathrm{P} \leq 0.05,(\mathrm{n}=2)$.

could influence carotenoid synthesis.

Many studies have attempted to explain the control of assimilate partitioning between sinks competing for a limited assimilate supply (Bangerth and Ho, 1984; Bertin 1995; DeJong and Walton, 1989; Demnitz-King et al., 1997; Pavel and DeJong, 1993). The activities of SS and AI are proposed as indicators of active sink strength for tomato (Wang et al., 1993; 1994) and peas (Déjardin et al., 1997; Sung et al., 1994). SS is positively correlated with relative fruit growth rate and the starch content of the tomato mesocarp (Wang et al., 1993). SS apparently played a role in papaya fruit sink establishment (Fig. 2B), being very high in 14 DAA fruit, then declined to $\approx 15 \%$ of the initial values at 70 DAA fruit. SS may maintain sink strength by cleavage of imported sucrose and providing UDP-glucose for biosynthetic reactions, as suggested for tomato (Wang et al., 1993). When SS activity was calculated on a whole fruit basis, SS increased from 14 to 98 DAA, then remained constant throughout the remainder of fruit growth. During early fruit development, the carbon import rate into the mesocarp tissue was correlated to SS activity.

AI activity increased significantly during the last phase of papaya fruit growth (Figs. 2B and 5B), and was associated with an increased carbon import rate. A similar relationship between carbon import rate and fruit sucrose levels has been observed in tomato fruit (Walker and Hawker, 1976). AI has been negatively correlated with the sucrose content in the starch accumulating apple [Malus sylvestris (L.) Mill var domestica (Borkh.) Mansf.] (Yamaki and Ishikawa, 1986), grape (Vitus vinifera L.) (Hawker, 1969), tomato (Klann et al., 1993; Miron and Schaffer 1991; Yelle et al., 1991), musk melon [Cucumis melo L. (Reticulatus Group)] (Lingle and Dunlap, 1987), and cucumber (Cucumis sativus L.) (Schaffer et al., 1987). In some tissues, monosaccharide content has shown a positive relationship with invertase activity (Ranwala et al., 1992; Walker and Hawker, 1976). However, low AI activity does not necessarily lead to accumulation of sucrose in some tomato genotypes (Miron and Schaffer, 1991), and no correlation is found between sucrose content and AI activities in 23 pear (Pyrus communis L.) cultivars (Moriguchi et al., 1992). However, unlike papaya, these fruit accumulate starch, whereas, in the wild tomato species (Lycopersicon chemielewskii $\mathrm{L}$.) AI is involved in sucrose accumulation (Klann et al., 1993; Yelle et al., 1991). The mesocarp sugar increase (Fig. 2A) in papaya paralleled the increase in AI activity (Fig. 2B) during the last phase of papaya fruit development and suggested a role for this enzyme in sugar accumulation. The increase in AI enzyme activity occurred slightly before the sugar increased. The peak in AI activity occurred 2 weeks before fruit ripening com- menced (Figs. 2 and 5) then declined to $60 \%$ to $70 \%$ of the peak before ripening began (Fig. 2B). When the invertase enzyme activity was compared to the sugar concentration $14 \mathrm{~d}$ earlier, the linear correlation coefficient was higher. The loss of soluble invertase activity and the high SPS would prevent further sucrose hydrolysis, and is thought to allow sucrose accumulation in muskmelon (McCollum et al., 1988) and tomato (Hubbard et al., 1989; Miron and Schaffer, 1991; Yelle et al., 1991).

No correlation was found between papaya fruit sugar levels and SPS or SS activity during fruit development. The reduced invertase activity 2 weeks before ripening commenced (Fig. 2B) together with an increased SPS activity (Fig. 2C) could contribute to sucrose accumulation in the vacuole. However, the observed increase in SPS (Fig. 2C) did not coincide with the maximum rate of sucrose accumulation (Fig. 2A) and may therefore be less important in sugar accumulation. In papaya, final fruit sugar apparently relied on continued sucrose import rather than starch degradation, as papaya mesocarp does not contain measurable starch or other carbohydrate storage compounds (Paull, 1993).

Decreased SS activity and increased AI activity were observed in all four cultivars and one breeing line during fruit ripening (Table 4). Nevertheless, the sucrose content in papaya fruit ripened after harvest remained relatively constant (Table 3) suggesting continued transfer of sugar from the plant was necessary for accumulation. No clear relationship existed between SPS, SS, and invertase activity and the sugar composition of mature harvested papaya, that were allowed to ripen. The higher level of SS and lower invertase and SPS in UH801 (larger fruit, lower sugar) suggested that the difference between these three enzymatic activities contributed to the difference in each cultivars' sugar concentration. The observed relationship can be explained by the high invertase activities detected in vitro, however, this may not have occurred in vivo, or the enzyme activity and sucrose were not be in the same cellular compartment of the fruit cell (Hubbard et al., 1991).

The optimal AI assay $\mathrm{pH}$ and the high solubility in extraction buffer suggested the invertase present during papaya fruit ripening is vacuolar (Chan and Kwok 1976; Lopez et al., 1988), not apoplastic. Loss of sucrose during homogenization and extraction, without heat inhibition of invertase (Chan and Kwok, 1976), implies that the sucrose and invertase could be either physically separated or the invertase is inhibited in vivo (Hubbard et al., 1991). The possibility of the invertase activity during fruit ripening being located in ripe papaya fruit flesh cell walls could not be excluded, as only buffer soluble activity was measured in the present study. 
Apoplastic sugar increased during fruit maturation and ripening in pears and accounted for $\approx 40 \%$ of the total sugars (Yamaki et al., 1993). Ripe papaya contains $\approx 40 \%$ to $60 \%$ sucrose (Chan et al., 1979; Chen, 1964), and in this respect is similar to pears (Yamaki et al., 1993). The lower invertase activity in UH801 during postharvest ripening (Table 4) was consistent with the lower invertase activity (Fig. 5B) and lower sugar accumulation before harvest (Table 1). However, it was not clear, if the same invertase isoform existed before and after harvest or during ripening and if different cultivars had different isoforms or how invertase enzyme activity was regulated in papaya fruit in vivo.

In conclusion, sucrose synthase was a major sugar enzyme activity (Fig. 2B) that correlated with fruit respiration (Fig. 1E) and carbon import rate (Fig. 4C) during early fruit growth. 'Sunset', 'Kapoho' and UH 801 papaya showed that AI activity just prior to full maturity was correlated with sugar accumulation by fruit (Fig. 2B). Isolation of the genes for these two enzymes and knowledge of their expression patterns would be the next step in potential modification of fruit growth and sugar accumulation. Control of the expression of these genes in transgenic papaya fruit using selective fruit development specific promoters would be essential. Alteration of the expression patterns could significantly alter source-sink relationships including overall papaya plant growth and fruit growth.

\section{Literature Cited}

Bangerth, F. and L.C. Ho. 1984. Fruit position and fruit set sequence in a truss as factors determining final fruit size of tomato fruits. Ann. Bot. 53:315-319.

Bertin, N. 1995. Competition for assimilates and fruit position affect fruit set in indeterminate greenhouse tomato. Ann. Bot. 75:55-65.

Chan, H.T., L.H. Kenneth, T. Goo, and E.K. Akamine. 1979. Sugar composition of papaya during fruit development. HortScience 14:140-141.

Chan, H.T. and S.C.M. Kwok. 1976. Isolation and characterization of a $\beta$ fructofuranosidase from papaya. J. Food. Sci. 41:320-323.

Chen, N. 1964. Some chemical changes during the postharvest ripening of papaya fruit. Bot. Bul. Acad. Sinica 1:89-99.

Clegg, M.D., C.Y. Sullivan, and J.D. Eastin. 1978. A sensitive technique for the rapid measurement of carbon dioxide concentration. Plant Physiol. 62:924-926.

Déjardin, A., C. Rochat, S. Maugenest, and J.P. Boutin. 1997. Purification, characterization and physiological role of sucrose synthase in the pea seed coat (Pisum sativum L.). Planta 201:128-137.

DeJong, T.M. and E.F. Walton. 1989. Carbohydrate requirements of peach fruit growth and respiration. Tree Physiol. 5:329-335.

Demnitz-King, A., L.C. Ho, and D.A. Baker. 1997. Activity of sucrose hydrolyzing enzymes and sugar accumulation during tomato fruit development. Plant Growth Regulat. 22:193-201.

Gross, K.C. 1988. A rapid and sensitive spectrophotometeric method for assaying polygalacturonase using 2-cyanoacetamide. HortScience 17:933-934.

Hawker, J.S. 1969. Changes in the activities of enzymes concerned with sugar metabolism during the development of grape berries. Phytochemistry 8:9-17.

Huang, T.B., R.L. Darnell, and K.E. Koch. 1992. Water and carbon budgets of developing citrus fruit. J. Amer. Soc. Hort. Sci. 117:287-293.

Hubbard, N.L., S.C. Huber, and D.M. Pharr. 1989. Sucrose phosphate synthase and acid invertase as determinants of sucrose concentration in developing muskmelon ( $\mathrm{Cucu}$ mis melo L.) fruits. Plant Physiol. 91:1527-1534.

Hubbard, N.L., D.M. Pharr, and S.C. Huber. 1991. Sucrose phosphate synthase and other sucrose metabolizing enzymes in fruits of various species. Physiol. Plant 82:191-196.

Klann, E.M., R.T. Chetelat, and A.B. Bennett. 1993. Expression of acid invertase gene controls sugar composition in tomato (Lycopersicon) fruit. Plant Physiol 103:863
870.

Lingle, S.E. and J.R. Dunlap. 1987. Sucrose metabolism in netted muskmelon fruit during development. Plant Physiol 84:386-389.

Lopez, M.E., M.A. Vattuone, and A.R. Sampietro. 1988. Partial purification and properties of invertase from Carica papaya fruits. Biochemistry 27:3077-3081.

McCollum, T.G., D.J. Huber, and D.J. Cantliffe. 1988. Soluble sugar accumulation and activity of related enzymes during muskmelon fruit development. J. Amer. Soc. Hort. Sci. 113:399-403.

Miron, D. and A.A. Schaffer. 1991. Sucrose phosphate synthase, sucrose synthase, and invertase activities in developing fruit of Lycopersicon esculentum Mill. and the sucrose accumulating Lycopersicon hirsutum Humb. and Bonpl. Plant Physiol. 95:623-627.

Moriguchi, T., K. Abe, T. Sanada, and S. Yamaki. 1992. Levels and role of sucrose synthase, sucrose phosphate synthase, and acid invertase in sucrose accumulation in fruit of Asian pear. J. Amer. Soc Hort Sci 117:274-278.

Moriguchi, T. and S. Yamaki. 1988. Purification and characterization of sucrose synthase from peach (Prunus persica) fruit. Plant Cell Physiol 29:1361-1366.

Nakasone, H.Y. 1986. Papaya, p. 277-301. In: P.S. Monselise (ed.). CRC handbook of fruit set and development. CRC Press, Inc., Boca Raton, Fla.

Paull, R.E. 1993. Pineapple and papaya, p. 302-323. In: G.B. Seymour, J.E. Taylor, and G.A. Tucker (eds.). Biochemistry of fruit ripening. Chapman \& Hall, London.

Paull, R.E., N.J. Chen, J. Deputy, H. Huang, G. Cheng, and F. Gao. 1984. Litchi growth and compositional changes during fruit development. J. Amer. Soc. Hort. Sci. 109:817-821.

Pavel, E.W. and T.M. DeJong. 1993. Source- and sink-limited growth periods of developing peach fruits indicated by relative growth analysis. J. Amer. Soc. Hort. Sci. 118:820-824.

Qiu, Y., M.S. Nishina, and R.E. Paull. 1995. Papaya fruit growth, calcium uptake, and fruit ripening. J. Amer. Soc. Hort. Sci. 120:246-253.

Ranwala, A.P., C. Suematsu, and H. Masuda. 1992. Soluble and wall-bound invertases in strawberry fruit. Plant Sci. 84:59-64.

Schaffer, A.A., B. Aloni, and E. Fogelman. 1987. Sucrose metabolism and accumulation in developing fruit of Cucumis. Phytochemistry 26:1883-1887.

Selveraj, Y. and D.K. Pal. 1982. Fruit set and developmental pattern of fruits of five papaya varieties. Indian J. Hort. 39:50-56.

Selveraj, Y., D.K. Pal, M.D. Subramanyam, and C.P.A. Iyer. 1982. Changes in the chemical composition of four cultivars of papaya (Carica papaya L.) during growth and development. J. Hort. Sci. 57:135-143.

Sung, S.J., W.J. Shieh, D.R. Geiger, and C.C. Black. 1994. Growth, sucrose synthase, and invertase activities of developing Phaseolus vulgaris L. fruits. Plant, Cell Environ. 17:419-426.

Walker, K.R. and J.S. Hawker. 1976. Effect of pollination on carbohydrate metabolism in young fruits of Citrullus lanatus and Capsicum annuum. Phytochemistry 15:18811884.

Wang, F., A. Sanz, M.L. Brenner, and A. Smith. 1993. Sucrose synthase, starch accumulation, and tomato fruit sink strength. Plant Physiol. 101:321-327.

Wang, F., A.G. Smith, and M.L. Brenner. 1994. Temporal and spatial expression pattern of sucrose synthase during tomato fruit development. Plant Physiol. 104:535540.

Yamaki, S. 1995. Physiology and metabolism of fruit development Biochemistry of sugar metabolism and compartmentation in fruits. Acta Hort. 398:109-120.

Yamaki, S., M. Ino, S. Ozak, Y. Tsuchimoto, and J. Ofosu-Anim. 1993. Cellular compartmentation and transport into plastid vesicles of sugars with ripening of pear fruit. Acta Hortic. 343:12-17.

Yamaki, S. and K. Ishikawa. 1986. Roles of four sorbitol related enzymes and invertase in the seasonal alteration of sugar metabolism in apple tissue. J. Amer. Soc. Hort. Sci. 111:134-137.

Yamamoto, H.Y. 1964. Comparison of carotenoids in yellow and red-fleshed Carica papaya. Nature 201:1049-1050.

Yelle, S., R.T. Chetelat, M. Dorais, J.W. DeVerna, and A.B. Bennett. 1991. Sink metabolism in tomato fruit. iv. Genetic and biochemical analysis of sucrose accumulation. Plant Physiol. 95:1026-1035.

Young, T.E., J.A. Juvrik, and J.G. Sullivan, 1993. Accumulation of the components of total soluble solids in ripening fruits of tomato. J. Amer. Soc. Hort. Sci. 118: 286-292.

Zhou, L.L., D.A Christopher, and R.E. Paull, 2000. Defoliation and fruit removal effects on papaya fruit production, sugar accumulation, and sucrose metabolism. J. Amer. Soc Hort Sci. 125:644-652. 